SOUNDTRACK OF THE REVOLUTION 
Stanford Studies in Middle Eastern and Islamic Societies and Cultures 


\section{SOUNDTRACK OF THE}

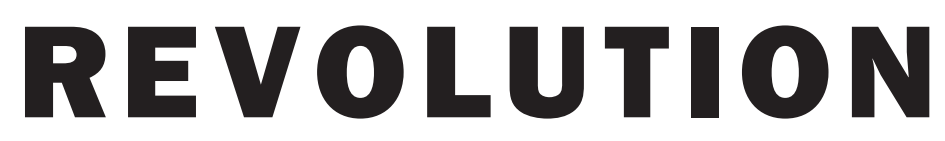

THE POLITICS OF MUSIC IN IRAN

NAHID SIAMDOUST 
Stanford University Press

Stanford, California

@2017 by Nahid Siamdoust. All rights reserved.

No part of this book may be reproduced or transmitted in any form or by any means, electronic or mechanical, including photocopying and recording, or in any information storage or retrieval system without the prior written permission of Stanford University Press.

Printed in the United States of America on acid-free, archival-quality paper Library of Congress Cataloging-in-Publication Data

Names: Siamdoust, Nahid, author.

Title: Soundtrack of the revolution : the politics of music in Iran / Nahid Siamdoust.

Other titles: Stanford studies in Middle Eastern and Islamic societies and cultures.

Description: Stanford, California : Stanford University Press, 2017. |

Series: Stanford studies in Middle Eastern and Islamic societies and cultures | Includes bibliographical references and index.

Identifiers: LCCN 2016020201 (print) | LCCN 2016020972 (ebook) | ISBN 9780804792899 (cloth : alk. paper) | ISBN 9781503600324 (pbk. : alk. paper) | ISBN 9781503600966 (ebook)

Subjects: LCSH: Music-Political aspects-Iran-History. | Iran-Politics and government-1979-1997. | Iran-Politics and government-1997-

Classification: LCC ML3917.I7 S49 2017 (print) | LCC ML3917.I7 (ebook) |

DDC 780.955/09048-dc23

LC record available at https://lccn.loc.gov/2016020201

Typeset by Bruce Lundquist in 10/14 Minion Pro 
In memory of my father, Mir Ali Akbar Seyed Siamdoust

Dedicated to my mother, Hamideh Seraj Ansari And my beautiful daughters, Delara \& Leili 
Join our path, dear one

Join our path, dear one

Don't remain alone with this pain

Because this shared pain

Never will be

Separately cured

-Mohammad Reza Shajarian's new encore "Razm-e moshtarak" (Common Battle), on his concert tour following the 2009 election unrest, a song that he first sang at the time of the revolution in 1979

Only words of steel remain

Public trust has been shattered

One day, though, the money you usurp

Shall choke you in your throat

I said it to the door

But the walls take note, word for word

-Alireza Assar's “Khiābān-khābhā” (Street-Sleepers), released in 2001 but reused by Green Uprising supporters over footage of government repression in 2009 
You are the most beloved wife of God

So much so that he even divorced Mohammad for you

-Mohsen Namjoo's "homage" to Supreme Leader Ayatollah Ali Khamenei, titled "Gelādiyātorhā" (Gladiators), 2009

After all this rain of blood

Finally, a rainbow will shine

The sky won't appear cloudy from all the stones

The aqueducts won't turn red like tulips

Muezzin, call to prayer

-Hichkas's "Yeh ruz-e khub miyād" (A Good Day Will Come), released online as he boarded the plane to leave Iran indefinitely, following the 2009 unrest 
